Canadian

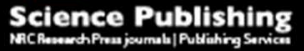

Canadian Journal of Civil Engineering Revue canadienne de génie civil

\title{
USE OF NORMAL-DENSITY HIGH-ABSORPTION LIMESTONE AGGREGATE AS INTERNAL CURING AGENT IN CONCRETE
}

\begin{tabular}{|r|l|}
\hline Journal: & Canadian Journal of Civil Engineering \\
\hline Manuscript ID & cjce-2014-0109.R2 \\
\hline Danuscript Type: & Article \\
\hline Complete List of Authors: & $\begin{array}{l}\text { Solís-Carcaño, Romel Gilberto; Autonomous University of Yucatan, College } \\
\text { of Engineering } \\
\text { Terán-Marín, Laura Valeria; Autonomous University of Yucatan, College of } \\
\text { Engineering } \\
\text { Moreno, Eric Ivan; Autonomous University of Yucatan, College of } \\
\text { Engineering }\end{array}$ \\
\hline Keyword: & $\begin{array}{l}\text { MP - concrete < Engineering Materials, high absorption aggregate, internal } \\
\text { curing, porosity, air permeability }\end{array}$ \\
\hline &
\end{tabular}




\title{
USE OF NORMAL-DENSITY HIGH-ABSORPTION LIMESTONE AGGREGATE AS INTERNAL CURING AGENT IN CONCRETE
}

\author{
Rómel Solís-Carcaño, Laura V. Terán-Marín, Eric I. Moreno* \\ Universidad Autonoma de Yucatan, College of Engineering, Ave. Industrias No Contaminantes s/n, \\ Merida, Yucatan, Mexico \\ * Corresponding author: Rómel Solís-Carcaño Tel: +52-999-9300568; E-mail address: \\ tulich@correo.uady.mx (R. Solis)
}




\section{ABSTRACT}

A common practice to provide additional water for the hydration process of cement is to use special aggregates that act as agents incorporating water to the concrete (lightweight natural aggregates or polymers). Previous studies have suggested that normal-density high-absorption limestone aggregates may produce a similar effect. The aim was to determine if they may function as internal curing agent. The methodology consisted of concrete specimens employing two types of aggregates and subjected to three different curing treatments. Results showed similar values of compressive strength and porosity among the concrete cured under wet and dry treatments for the high-absorption limestone aggregate but not for the river rock aggregate. Thus, this effect was attributed to the internal curing properties of the high-absorption limestone aggregate.

Keywords: air permeability, concrete, high absorption aggregate, internal curing, porosity

\section{INTRODUCTION}

Keeping concrete humid as long as possible, after casting, is of paramount importance in order to generate the maximum amount of hydrated solid products from Portland cement compounds; this enables a low porosity/low permeability cement paste, increasing the concrete's mechanical strength and making difficult the penetration and diffusion of aggressive environmental agents.

Currently, it is accepted that curing water externally applied in a concrete element only affects a superficial layer 30 to $50 \mathrm{~mm}$ depth (Neville 2011). As compounds 
are hydrating, cement paste becomes more impervious, and it is increasingly difficult for the externally applied curing water to move inside the concrete. Parrot's experimental work (1988) showed that the moisture movement inside concrete is limited to $35 \mathrm{~mm}$ depth after 172 days for a concrete mixture with w/c of 0,59 .

Since little more than a decade, internal curing has been considered as an alternative medium to provide water to the cement hydration from the freeing of absorbed water in the aggregates (Bentz and Weiss 2011). Klieger (1957) is maybe the first one to glance the potential of this curing technique while publishing that lightweight aggregates absorb a considerable amount of water during mixing and that water could transfer to the paste during hydration.

Internal curing is defined as supplying water throughout a freshly placed cement mixture using wetted lightweight aggregates that release water as needed for hydration (ACI CT-13 2013).

This curing technique is especially helpful in concretes with low w/c, due to the high amount of cement involved that, in one way, makes critical the phenomena of self-desiccation produced by the exothermic reactions of the cement hydration; and, in another way, makes low permeability concretes that difficult water mobility inside concrete. Internal curing allows that the freed absorbed water from the aggregates distributes uniformly and provides water to the paste system (Bentz et al. 2005), which promotes hydration of cement as much as possible.

In order for the internal curing to proceed, the water reservoir contained inside the aggregate should be easily released. Water mobility, from the aggregates toward the paste, begins in the biggest pores and continues with the ones with lower 
diameter as the first ones are depleted. As certain critical pore diameter is reached, water does not have the energy to be transferred and the internal curing ends.

The internal curing effect could begin immediately after cement hydration starts.

During the first hours cement paste is highly permeable, so that the water is able to move easily, up to $2 \mathrm{~mm}$ from the internal reservoir source; after 28 days, permeability of the cement paste has diminished considerably, and water mobility is limited to 100 to $200 \mu \mathrm{m}$ (Bentz and Snyder 1999).

Common practice to promote internal curing consists in employing special aggregates that function as agents incorporating water to the cement. There are two types of agents: natural lightweight aggregates (as vermiculite, perlite, pumice, etc.) and super absorbent polymers; in both cases, a percentage of normal aggregate is substituted by the special aggregate that works as curing agent. The amount of absorbent aggregates necessary in a mixture to obtain an efficient internal curing has been modeled based on the amount and chemical shrinkage of cement, the expected degree of hydration, and the absorption and degree of water saturation of the aggregate (Bentz and Snyder 1999; Bentur et al. 2001).

The study reported in this paper was performed in the Yucatan peninsula. In this region, crushed limestone aggregate is used for concrete. Unlike other types of aggregates -as the igneous rocks- limestone exhibit wide variability in its properties due to the original layered sediments; the above is due to the specific conditions under which the limestone were consolidated, by area and strata.

The mechanical strength of the limestone of this region is relatively low. Results of mechanical tests on these rocks have been published (Espinoza et al. 1996), the 
average values being reported as follows: compressive strength $27,5 \mathrm{MPa}$, relative density 2,2, absorption 7,1\%, modulus of elasticity $118017 \mathrm{MPa}$. In contrast, other limestone regions with low absorption tend to have compressive strengths greater than 98,1 MPa (Ortiz et al. 1995).

The level at which the rocks are extracted which are used to produce aggregates in the Yucatan peninsula is variable but is generally above the location where the pore water pressure is under atmospheric conditions (i.e. the water table). As the operating depth of the layer becomes higher, the rock becomes less compact; this circumstance leads to variability in the characteristics of the rocks, and consequently in the aggregates. In the particular case of Merida, capital of Yucatan state, the average water table level is $7,00 \mathrm{~m}$.

Moreover, limestone aggregates have great influence on the nature of the micro structure of the interface transition zone (ITZ) between the aggregates and the cement paste. Chemical interaction between these rocks and cement paste can lead to an increase in adhesion strength between the two phases. The limestone reacts with the cement paste and produces a large amount of pores in the ITZ, which at an early age results in a decrease in adhesion strength. However, at older ages, these pores are filled with subsequent hydration products, which increase the adhesion force (Tasong 1999).

The geological composition of the Yucatan Peninsula consists of antigenic carbonates and anhydrite, precipitated from the Lower Cretaceous, Aptian until the Miocene. This peninsula is covered almost entirely of Tertiary marine sediments, which are becoming younger northward (López-Ramos 1981). 
The chemical composition of this limestone, obtained from samples taken at Merida (Pacheco and Alonzo 2003), is the following: $77 \%$ calcium carbonate and $13 \%$ magnesium carbonate, in addition to $2,25 \%$ of clay and $1,11 \%$ silicon dioxide; other compounds identified were: iron oxide $(0,08 \%)$, sulfates $(0,004 \%)$, nitrate $(0,004 \%)$ and chloride $(0,002 \%)$.

Table 1 presents the statistical parameters of the physical properties calculated from ten samples of aggregates, which were characterized in a previous study (Solís and Moreno 2008). One can observe that the mean relative density of the gravel was less than 2,4 , which is the limit for normal-weight aggregate (ASTM C 125 2011). Also, the average absorption for both aggregates was greater than $4,0 \%$. The original report shows that the absorption of about half the samples are within the limits of the measured values of lightweight aggregates that are often used as internal curing agents $-6 \%$ to $30 \%$ (Castro et al. 2011). In contrast, normal aggregates used in concrete have absorption levels in the range of $0,2 \%$ to $4 \%$ for coarse aggregate and 0,2 to $2 \%$ for fine aggregate (Kosmatka and Panarese 2002).

Previous work with concrete made with the aggregates described above, have suggested that this specific type of aggregate can produce an internal curing; the above on the basis that no significant differences were found between the mechanical strength of standard and naturally cured concrete specimens (Solís and Moreno 2005, Solís et al. 2011).

An alternative hypothesis to explain the standard curing minimal effect on the compressive strength, has been considering the possibility that the tropical 
environment of the Yucatan peninsula provide the necessary conditions for naturally curing (Moreno et al. 2008).

According to the Köppen-Geiger-Pohl climate classification, published by Vladimir Köppen in 1936 and revised in 1953, the climate of the Yucatan Peninsula Aw represents what is generically known as Tropical savanna climate. The climate group represented by the letter $A$ means tropical rainforest, and is defined by the following characteristics: all months have an average temperature above $18{ }^{\circ} \mathrm{C}$, there is no winter season, and the rains are abundant. While $w$, which represents the subgroup -which depends on the humidity-, means dry winter season (Huntley and Walker 1985).

The objective of the present investigation was to determine if the normal-density high-absorption limestone aggregate behaved as an internal curing agent for concrete; in order to do so, results of the compressive strength, porosity and permeability of concrete subjected to three different curing treatments were compared.

\section{METHODOLOGY}

To observe the effects of internal curing attributable to the absorption of the aggregates proof of the release of water from that absorbed by the aggregates should be attained by a desorption curve. After that, three different curing treatments were applied to concrete specimens produced in laboratory: cured by immersion in water, which was named T1; natural curing environment under 
shade, which was designated T2; and cured under controlled temperature $(22 \pm$ $\left.0.5^{\circ} \mathrm{C}\right)$ and relative humidity $(60 \pm 5.0 \%)$, which was designated T3.

T1 treatment is sought to have the optimal condition of humidity and moisture in the concrete; with T2 is sought to limit concrete moisture which may obtain from both the environment and the absorption of the aggregates; and with T3 treatment is sought a condition of low humidity, which would force the release of moisture from the aggregates.

The unit of analysis of the study was the concrete prepared with a specific type of high-absorption limestone aggregates. To compare measurements made on them, concrete specimens with low absorption aggregate were prepared; these were: marble gravel and silica sand.

Three types of concrete were prepared: with limestone aggregates $(\mathrm{L})$, marble gravel and silica sand (MS) and marble gravel and limestone sand (ML). For the first type concrete specimens were manufactured with two different aggregate samples (concrete L1 and L2) from the same geological region, seeking to observe the variability of the results for the same type of aggregate. For concrete type MLa third fine aggregate limestone (Ims.) sample was used. Table 2 shows the physical properties measured on samples of the aggregates used.

All concrete mixtures were designed using the $\mathrm{ACl}$ by absolute volume method (ACl 211 1991). Concrete mixture employed 0,50 water to cement ratio and compound Portland cement similar to ASTM type I, with lime addition (ASTM C 
150 2012). Mixture proportions are presented in Table 3 for the four concrete mixtures employed.

Aggregates before mixing had about $50 \%$ of the absorption. Water was added up to $80 \%$ of the total aggregate absorption to compensate absorption during mixing. Also, it can be observed that mixture MS required less amount of water due to the smooth surface of the aggregates employed.

The different types of concrete were manufactured in the laboratory; the following day after molding, the specimens were randomly assigned to one of three treatments curing (T1, T2 y $\mathrm{T} 3)$.

The variables that were measured in the concrete, as an indirect way of observing the cement hydration, were: compressive strength (ASTM C 39 2012), porosity (ASTM C 642 2013) and permeability (SIA 262/1-E 2003). The first one after 28 and 90 days of casting, and the last two after 90 days of casting. If not enough curing is provided, then compressive strength should be lower than expected and porosity and permeability of the material should be higher than expected.

To measure compressive strength, test cylinders $15 \mathrm{~cm}$ in diameter by $30 \mathrm{~cm}$ tall were used; for porosity, test cylinders $10 \mathrm{~cm}$ in diameter by $20 \mathrm{~cm}$ tall were used; and for permeability, prismatic specimens $15 \mathrm{~cm}$ by $15 \mathrm{~cm}$ by $60 \mathrm{~cm}$ were used. Three repetitions of the measurements were performed, and three replicates of the experiment were completed.

Data analysis consisted of descriptive statistics (mean and standard deviation) of the three variables. Analysis of variance (ANOVA) of variables, in order to 
determine significant differences of means attributable to the three curing treatments was performed; Fisher-Snedecor statistic was calculated and a minimum significance level of 0.05 was considered. When statistical differences were determined post hoc Scheffé multiple comparisons test was performed to determine which combinations of treatments means were different.

Climatic conditions in which the experiment was conducted is shown in Figures 1 and 2. In the first figure, the average, minimum and maximum temperatures of each day are plotted during the period in which the specific T2 treatment were exposed to the environment, and in the second figure, the average, minimum and maximum relative humidity of each day are plotted during the same period.

\section{RESULTS}

The results of the desorption curved are shown in Figure 3. It can be observed that almost $40 \%$ is released at $80 \% \mathrm{RH}$, and more than $90 \%$ is released at $70 \%$, thus proving that the water is released when it is needed for continuing curing the cement paste.

Figure 4 shows the development with time of the compressive strength of concrete with limestone aggregates $(L ' s)$; in this graph it is considered as one group concretes prepared with the two samples of this type of aggregate ( $L 1$ and $L 2$ ), for all three curing treatments

In the same manner, Figures 5 and 6 shows the development with time of the compressive strength of concrete manufactured with marble-silica (MS) and marble-limestone (ML) aggregates, respectively. 
Analyses of variance (ANOVA) were performed to test the statistical difference in mean compressive strength of concrete types subject to three different curing treatments. The results are shown in Table 4, where it can be seen that for the two test ages, according to the significance values, the means of resistance were different for concrete types MS and ML.

From post hoc test for multiple comparisons pairs of compressive strength means that were statistically different were identified. At the age of 28 days, for the concrete type MS compressive strength means were different for the following combinations of treatments: T1 - T2 (significance 0,001) and T1 - T3 (significance $<0,001$ ) and for the concrete type ML, for combination T1 - T3 (significance 0,001). At 90 days, for both types of concrete the compressive strength means were different for the following combinations of treatments: T1 - T2 (significance $<0,001$ for MS and 0,002 for ML) and T1 - T3 (significance <0,001 for both).

The results of the porosity testing at 90 days are presented in Table 5, which contains the mean and standard deviation for each type of concrete and for each of three curing treatments applied. In the same way as for the compressive strength, also presents the average and standard deviation of the porosity of concrete with limestone, given as a single group $(L ' s)$, of the concrete made with the two samples of this type of aggregate.

Analysis of variance from porosity tests showed significant mean differences only for concrete manufactured with marble-silica aggregates (MS), for different curing treatments (significance 0,001). 
From post hoc test for multiple comparisons of porosity for concrete type MS, combinations of T1 - T2 (significance 0,002 ) and T1 - T3 (significance 0,003) were identified as statistically different.

The test results of air permeability measured after 90 days are presented in Table 6 , which contains the mean and standard deviation for each type of concrete manufactured for each of the three curing treatments applied. It also presents the results considered as a single group $(L ' s)$, of the concrete made with the two samples of limestone aggregate.

Analyses of variance (ANOVA) were performed to test the statistical difference in mean permeability of concrete types subjected to three different curing treatments. The results are shown in Table 7, in which it can be seen that, according to the significance values for all types of concrete, permeability differ between some of the curing treatments.

From post hoc test for multiple comparisons pairs of permeability means that were statistically different were identified. Table 8 is a summary of the values of the significance of the comparisons between the curing treatments for each type of concrete. It can be seen that all comparisons between $\mathrm{T} 1$ and $\mathrm{T} 3$ showed significant differences in the means, as well as comparisons between T1 and T2 (with the exception of the concrete type L1); on the contrary, no comparison between T2 and T3 showed significant difference

\section{DISCUSSION}


Using absorbent limestone aggregates, which are the subject of this study, no significant differences were found in mean compressive strength when the curing treatment was varied (standard, natural and low humidity controlled environment), the above for the two ages tested ( 28 and 90 days). This result is consistent with previous studies employing the same type of aggregates and under the same tropical environment (Solís and Moreno 2005, 2011, Solís et al. 2011).

For non absorbent concrete aggregates (marble-silica) differences were found in the compressive strength when the curing treatment was varied. At the age of 28 days, concrete cured under natural environment had $73,9 \%$ of the compressive strength of standard cured concrete, and concrete cured under low humidity environment had $70,6 \%$ of that compressive strength; in both cases the means were significantly different from that of the standard cured concrete. At 90 days, concrete cured under natural environment had $67,7 \%$ of the compressive strength of standard cured concrete, and concrete cured under low humidity environment had $64,9 \%$ of that compressive strength; in both cases the means were significantly different from that of the standard cured concrete.

From the above, it can be assumed that in concrete with absorbent limestone aggregates, the degree of cement hydration was similar for all three curing treatments; whereby, for the case of concrete exposed to a low humidity curing environment, the cement paste should be kept in a state close to saturation. Evaporation, deliberately caused in these concretes, must be compensated by the effect of the release of water contained in these high porosity aggregates, i.e. by internal curing. In contrast, it can be assumed that in the non absorbent concrete 
aggregates the degree of cement hydration was lower when concrete was cured under natural and low humidity environments.

With regards to the possible effect of natural curing concrete, caused by tropical climate characteristics such as that of this study, no significant differences were found between the means of the compressive strength of concrete cured under natural and low humidity environments; the above, either for absorbent aggregates, as well as for non-absorbent. Therefore, it can be assumed that the degree of cement hydration for both environments were similar, and it cannot be assumed that the natural curing phenomenon is attributable to sub-humid climate, as suggested in a previous work in which compressive strength of concrete exposed to the same climate was tested (Moreno et al. 2008).

In the case of concrete made with non absorbent gravel (marble) and absorbent sand (limestone) similar results were obtained to the case discussed above with concrete made with both non absorbent aggregates. The only difference was that at 28 days of age, the compressive strength of concrete cured standard and under natural environment showed no significant difference, which itself was held at 90 days; at this age concrete cured under natural environment had $89.9 \%$ of the compressive strength of concrete with standard cure. From the foregoing, it can be assumed that the absorbent limestone sand alone also had an internal curing effect on the concrete, although the effect was smaller than that attributed to the combination of both absorbent aggregates. 
With respect to porosity, no significant differences in means were obtained in concrete with absorbent limestone aggregates when the curing treatment was varied; while for non-absorbent aggregates (marble-silica) differences in porosity were observed when the curing treatment was varied. The concrete cured under natural environment had a porosity of $105.0 \%$ of that of concrete with standard curing, and the concrete cured under low humidity environment had $109.2 \%$ of that porosity; in both cases the means of these values were significantly different from that of the average standard curing concrete. It was noted that the high porosity percentages that were measured are typical of concrete prepared with this type of aggregate (Solís and Moreno 2006).

From the porosity it can also be assumed that in the concrete with absorbent limestone aggregates the degree of cement hydration was similar for all three curing treatments. In contrast, it can be assumed that in concrete with non absorbent aggregates the degree of cement hydration was lower when the specimens remained in natural and low humidity environments.

With regard to permeability, significant differences were found in all the concrete mixtures when the curing treatment was varied. For absorbent aggregate concretes, those cured under natural environment had, on average, $3418 \%$ of the permeability measured with standard curing concrete, and was those cured in a low humidity environment had, on average, $5825 \%$ of that permeability. For non absorbent aggregate concrete, those cured under natural environment had $7145 \%$ of the permeability measured with standard curing concrete and those cured in a low humidity environment had $8850 \%$ of that permeability. For concrete with non 
absorbent gravel and absorbent sand aggregates, those cured under natural environment had $3522 \%$ of the permeability measured with standard curing concrete and in all cases the means of concrete cured under natural and low humidity environments were significantly different from the mean standard curing concrete.

From the foregoing, it can be assumed that the superficial layer of concretes cured under natural and low humidity environments had a degree of cement hydration much lower than the standard curing concrete; the previous is of utmost importance for the durability prognosis of them. According to the quality criteria defined from the air permeability test (SIA 262/1-E 2003), all standard curing concretes can be described as average to very good; while all concretes cured under natural and low humidity environments can be classified as poor concrete.

\section{CONCLUSIONS}

For concrete with normal-density high-absorption crushed limestone aggregates that were studied similar levels of porosity and compressive strength were reached, either in those with standard curing as well as those cured under natural environment and low humidity conditions; the above was possible due to the effect of internal curing.

The surface layer of concretes cured under natural environment and low humidity had a high level of permeability, which compromised their durability so they could be regarded as poor quality concrete; this shows the importance of the curing processes for the concrete to reach durability. 
In the tropical environment studied the effect of the natural curing of concrete was not observed.

\section{REFERENCES}

ACl CT-13. 2013. ACl concrete terminology. American Concrete Institute. Farmington Hills MI.

ACI 211.1-91. 1991. Standard practice for selecting proportions for normal, heavyweight, and mass concrete (reapproved 2002). American Concrete Institute. Farmington Hills MI.

ASTM C 39/C 39M. 2012. Standard test method for compressive strength of cylindrical concrete specimens. American Society for Testing and Materials. West Conshohocken PA.

ASTM C 125. 2011. Standard terminology relating to concrete and concrete aggregates. American Society for Testing and Materials. West Conshohocken PA.

ASTM C 150/C 150M. 2012. Standard specification for portland cement. American Society for Testing and Materials. West Conshohocken PA.

ASTM C 642. 2013. Standard test method for density, absorption, and voids in hardened concrete. American Society for Testing and Materials. West Conshohocken PA.

Bentur, A., Igarashi S., and Kovler, K. Prevention of autogenous shrinkage in highstrength concrete by internal curing using wet lightweight aggregates. Cem Concr Res. 31(11): 1587-91.

Bentz, D., and Snyder, K. 1999. Protected paste volume in concrete: extension to internal curing using saturated lightweight fine aggregate. Cem Concr Res. 29(11): 1863-7.

Bentz, D., and Weiss, W. 2011. Internal curing: A 2010 state-of-the-art review. Gaithersburg (MD): National Institute of Standards and Technology, Engineering Laboratory, Materials and Construction Research Division; Feb. Report No.: NISTIR 7765. Sponsored by the U.S. Department of Commerce.

Bentz, D., Lura, P., and Roberts, J. 2005. Mixture proportioning for internal curing. Concr Int. 27(2): 35-40. 
Castro, J., Keiser, L., Golias, M., and Weiss, J. 2011. Absorption and desorption properties of fine lightweight aggregate for application to internally cured concrete mixtures. Cem Concr Compos. 33(10): 1001-8.

Espinosa, L., Ceron, M., and Sulub, Y.A. 1996. Limestone rocks of the Yucatan Peninsula: Description of the lithology and physical properties based on the results of exploration, investigation and laboratory tests. Int J Rock Mech Min Sci Geomech Abstr. 35(7): 410-1.

Huntley, B.J., and Walker, B.H. 1985. Ecology of tropical savannas. Ecological studies series number 42. New York: Springer-Verlag.

Klieger, P. 1957. Early High strength concrete for prestressing. In: Proceedings World Conference on Prestressed Concrete; San Francisco, CA. p. A5.1-14.

Kosmatka, S.H., and Panarese, W.C. 2002. Design and control of concrete mixtures. 14th ed., Skokie IL, Portland Cement Association.

López-Ramos, E. 1981. Palaeography and Mesozoic tectonic in Mexico (in Spanish). Rev Mex Cienc Geol. 5(2): 158-77.

Moreno, E.I., Solís, R., and Serrano, C. 2008. Natural concrete curing under hot sub-humid climate. In Fifth ACl/CANMET International Conference on HighPerformance Concrete Structures and Materials ACI-SP253. Edited by E. Pazini, T. Holland, V. Malhotra, and P. Helene. Manaus, Brazil, 18-20 June 2008. American Concrete Institute, Farmington Hills MI, pp. 291-304.

Neville, A. 2011. Properties of concrete. 5th ed. Philadelphia: Trans-Atlantic Publications; 846 p.

Ortiz, P., Guerrero, M., and Galán, E. 1995. Petrographic and geochemical characterization of the limestones of the Sierra Estepa (Sevilla) and evaluation of the technical quality as building materials (in Spanish). Estud Geol. 51(5): 213-22.

Pacheco, J., and Alonzo, L. 2003. Characterization of limestone material from the Formacion Carrillo Puerto in Yucatan (in Spanish). Ing Rev Acad Fac Ing Univ Auton Yuc. 7(1): 7-19.

Parrott, L. 1988. Moisture profiles in drying concrete. Adv Cem Res, 1(3): 164-70.

SIA 262/1-E. 2003. Concrete - Additional requirements. Annex E: Air permeability on the structure. Swiss Standards Association. Zurich. 
Solís R., and Moreno, E.I. 2005. Influence of moist curing on the concrete compressive strength under hot sub-humid climate (in Spanish). Ing Rev Acad Fac Ing Univ Auton Yuc. 9(3): 5-17.

Solís, R., and Moreno, E.I. 2006. Porosity analysis of concrete made with limestone aggregate (in Spanish). Rev Fac Ing Univ Centr Venez. 21(3):57-68.

Solís, R., and Moreno, E.I. 2008. Evaluation of concrete made with crushed limestone aggregate base on ultrasonic pulse velocity. Constr Build Mater. 22(6): 1221-31.

Solís, R., and Moreno, E.I. 2011. Concrete made with limestone aggregate: under hot environment (in Spanish). Saarbrücken: Editorial Académica Española; 223 p.

Solís, R., Moreno, E.I., and Vázquez, C. 2011. Compressive strength differences between moist and ambient cured concrete in a hot sub-humid environment (in Spanish). J Concr Cem, Investig Desarr - IMCYC. 3(1): 25-35.

Tasong, W. 1999. Aggregate-cement paste interface. Cem Concr Res. 29(7): 1019-25.

Table 1. Statistical parameters of the physical properties from high absorption limestone aggregate.

\begin{tabular}{|l|c|c|c|c|c|c|c|c|}
\hline \multirow{2}{*}{$\begin{array}{l}\text { Statistical } \\
\text { parameter }\end{array}$} & \multicolumn{9}{|c|}{ Coarse } & \multicolumn{4}{c|}{ Fine } \\
\cline { 2 - 9 } & $\begin{array}{c}\text { CBDD } \\
\left(\mathrm{kg} / \mathrm{m}^{3}\right)\end{array}$ & $\begin{array}{c}\text { Relative } \\
\text { density }\end{array}$ & $\begin{array}{c}\text { Absorption } \\
(\%)\end{array}$ & $\begin{array}{c}\text { Degradation } \\
(\%)\end{array}$ & $\begin{array}{c}\text { LBDD } \\
\left(\mathrm{kg} / \mathrm{m}^{3}\right)\end{array}$ & $\begin{array}{c}\text { Relative } \\
\text { density }\end{array}$ & $\begin{array}{c}\text { Absorption } \\
(\%)\end{array}$ & $\begin{array}{c}\text { Fine } \\
(\%)\end{array}$ \\
\hline Mean & 1290 & 2,36 & 6,4 & 30 & 1332 & 2,48 & 4,9 & 17,5 \\
\hline $\begin{array}{l}\text { Standard } \\
\text { deviation }\end{array}$ & 63,6 & 0,08 & 1,8 & 7,5 & 76,3 & 0,04 & 0.8 & 4,0 \\
\hline Minimum & 1162 & 2,22 & 4,8 & 23 & 1153 & 2,42 & 4,1 & 14 \\
\hline Maximum & 1334 & 2,48 & 9,8 & 47 & 1408 & 2,55 & 6,5 & 26 \\
\hline
\end{tabular}

Table 2. Properties of employed aggregates.

\begin{tabular}{|c|c|c|c|c|c|c|c|}
\hline \multirow{2}{*}{ Property } & \multicolumn{2}{|c|}{ Lms. 1 } & \multicolumn{2}{c|}{ Lms. 2 } & Lms. 3 & Marble & Silica \\
\cline { 2 - 8 } & Coarse & Fine & Coarse & Fine & Fine & Coarse & Fine \\
\hline LBDD $\left(\mathrm{Kg} / \mathrm{m}^{3}\right)$ & 1057 & 1199 & 1224 & 1218 & 1193 & 1334 & 1578 \\
\hline CBDD $\left(\mathrm{Kg} / \mathrm{m}^{3}\right)$ & 1148 & --- & 1313 & --- & --- & 1357 & ---- \\
\hline Degradation $(\%)$ & 42 & --- & 29 & --- & --- & 24 & ---- \\
\hline Relative density & 2,20 & 2,28 & 2,38 & 2,38 & 2,40 & 2,70 & 2,65 \\
\hline Absorption $(\%)$ & 10,40 & 6,72 & 7,10 & 7,98 & 8.00 & 0,49 & 0,77 \\
\hline Fine modulus & --- & 3,19 & --- & 2,38 & 2,40 & --- & 2,65 \\
\hline
\end{tabular}


Table 3. Concrete mixture proportions by mass, saturated surface dry condition $\left(\mathrm{kg} / \mathrm{m}^{3}\right)$.

\begin{tabular}{|c|c|c|c|c|}
\hline \multirow{2}{*}{ Material } & \multicolumn{4}{|c|}{ Concrete Mixtures } \\
\cline { 2 - 5 } & L1 & L2 & MS & ML \\
\hline Cement & 460 & 460 & 400 & 460 \\
\hline Water & 230 & 230 & 200 & 230 \\
\hline Coarse Agg. & 733 & 832 & 813 & 777 \\
\hline Fine Agg. & 735 & 713 & 1012 & 768 \\
\hline
\end{tabular}

Table 4. Results of the analyses of variance of compressive strength subjected to three curing treatments.

\begin{tabular}{|c|c|c|c|c|}
\hline \multirow{2}{*}{$\begin{array}{c}\text { Concrete } \\
\text { Mixtures }\end{array}$} & \multicolumn{2}{|c|}{28 days } & \multicolumn{2}{c|}{90 days } \\
\cline { 2 - 5 } & F-test & Significance & F-test & Significance \\
\hline L1 & 0,183 & 0,837 & 3,113 & 0,118 \\
\hline L2 & 0,706 & 0,531 & 1,959 & 0,221 \\
\hline MS & 28,815 & $<0,001$ & 73,137 & $<0,001$ \\
\hline ML & 23,563 & 0,001 & 51,734 & $<0,001$ \\
\hline
\end{tabular}

Table 5. Porosity at 90 days for each of the three curing treatments (\%).

\begin{tabular}{|c|c|c|c|c|c|c|}
\hline \multirow{3}{*}{$\begin{array}{l}\text { Concrete } \\
\text { Mixtures }\end{array}$} & \multicolumn{6}{|c|}{ Curing Treatment } \\
\hline & \multicolumn{2}{|c|}{ T1 } & \multicolumn{2}{|c|}{ T2 } & \multicolumn{2}{|c|}{ T3 } \\
\hline & Average & \begin{tabular}{|l} 
Standard \\
Deviation
\end{tabular} & Average & $\begin{array}{l}\text { Standard } \\
\text { Deviation }\end{array}$ & Average & $\begin{array}{l}\text { Standard } \\
\text { Deviation }\end{array}$ \\
\hline L1 & 22,17 & 0,86 & 23,27 & 1,65 & 24,21 & 0,75 \\
\hline L2 & 21,43 & 0,69 & 22,10 & 0,66 & 22,62 & 1,23 \\
\hline L's & 21,80 & 0,52 & 22,69 & 0,82 & 23,42 & 1,12 \\
\hline MS & 22,17 & 0,86 & 23,27 & 1,65 & 24,21 & 0,75 \\
\hline $\mathrm{ML}$ & 21,43 & 0,69 & 22,10 & 0,66 & 22,62 & 1,23 \\
\hline
\end{tabular}

Table 6. Air permeability after 90 days for the three curing treatments $\left(10^{-6} \mathrm{~m}^{2}\right)$.

\begin{tabular}{|l|c|c|c|}
\hline $\begin{array}{l}\text { Concrete } \\
\text { Mixtures }\end{array}$ & T1 & T2 & T3 \\
\cline { 2 - 4 }
\end{tabular}




\begin{tabular}{|c|c|c|c|c|c|c|}
\hline & Average & $\begin{array}{c}\text { Standard } \\
\text { Deviation }\end{array}$ & Average & $\begin{array}{c}\text { Standard } \\
\text { Deviation }\end{array}$ & Average & $\begin{array}{c}\text { Standard } \\
\text { Deviation }\end{array}$ \\
\hline L1 & 0,212 & 0,061 & 5,256 & 1,949 & 9,707 & 3,484 \\
\hline L2 & 0,037 & 0,023 & 3,289 & 1,578 & 4,856 & 1,259 \\
\hline L's & 0,125 & 0,124 & 4,273 & 1,39 & 7,282 & 3,43 \\
\hline MS & 0,042 & 0,034 & 3,001 & 0,304 & 3,717 & 1,577 \\
\hline ML & 0,063 & 0,054 & 2,219 & 0,192 & 3,323 & 0,805 \\
\hline
\end{tabular}

Table 7. Results of the analyses of variance of air permeability of concrete subjected to three curing treatments.

\begin{tabular}{|c|c|c|}
\hline Concrete Mixture & F-test & Significance \\
\hline L1 & 12,742 & 0,007 \\
\hline L2 & 13,344 & 0,006 \\
\hline MS & 17,472 & 0,001 \\
\hline ML & 36,007 & $<0,001$ \\
\hline
\end{tabular}

Table 8. Significant values from post hoc test for multiple comparisons of permeability means after 90 days for concrete subjected to the three curing treatments.

\begin{tabular}{|c|c|c|c|c|c|c|}
\hline \multirow{2}{*}{$\begin{array}{c}\text { Concrete } \\
\text { Mixture }\end{array}$} & \multicolumn{6}{|c|}{ Curing Treatment } \\
\cline { 2 - 7 } & \multicolumn{2}{|c|}{ T1 } & \multicolumn{2}{|c|}{ T2 } & \multicolumn{2}{c|}{ T3 } \\
\hline & T2 & T3 & T1 & T3 & T1 & T2 \\
\hline L1 & 0,094 & 0,007 & 0,094 & 0,139 & 0,007 & 0,139 \\
\hline L2 & 0,039 & 0,007 & 0,039 & 0,327 & 0,007 & 0,327 \\
\hline MS & 0,005 & 0,001 & 0,005 & 0,565 & 0,001 & 0,565 \\
\hline ML & 0,004 & $<0,001$ & 0,004 & 0,079 & $<0,001$ & 0,079 \\
\hline
\end{tabular}


List of figure captions:

Figure 1. Average, minimum, and maximum temperatures of each day.

Figure 2. Average, minimum, and maximum relative humidity of each day.

Figure 3. Desorption curve of the limestone aggregate.

Figure 4. Development with time of the compressive strength of concrete with limestone aggregates ( $L$ 's) for each curing treatment.

Figure 5. Development with time of the compressive strength of concrete with marble-silica aggregates (MS) for each curing treatment.

Figure 6. Development with time of the compressive strength of concrete with marble-limestone $(\mathrm{ML})$ for each curing treatment. 


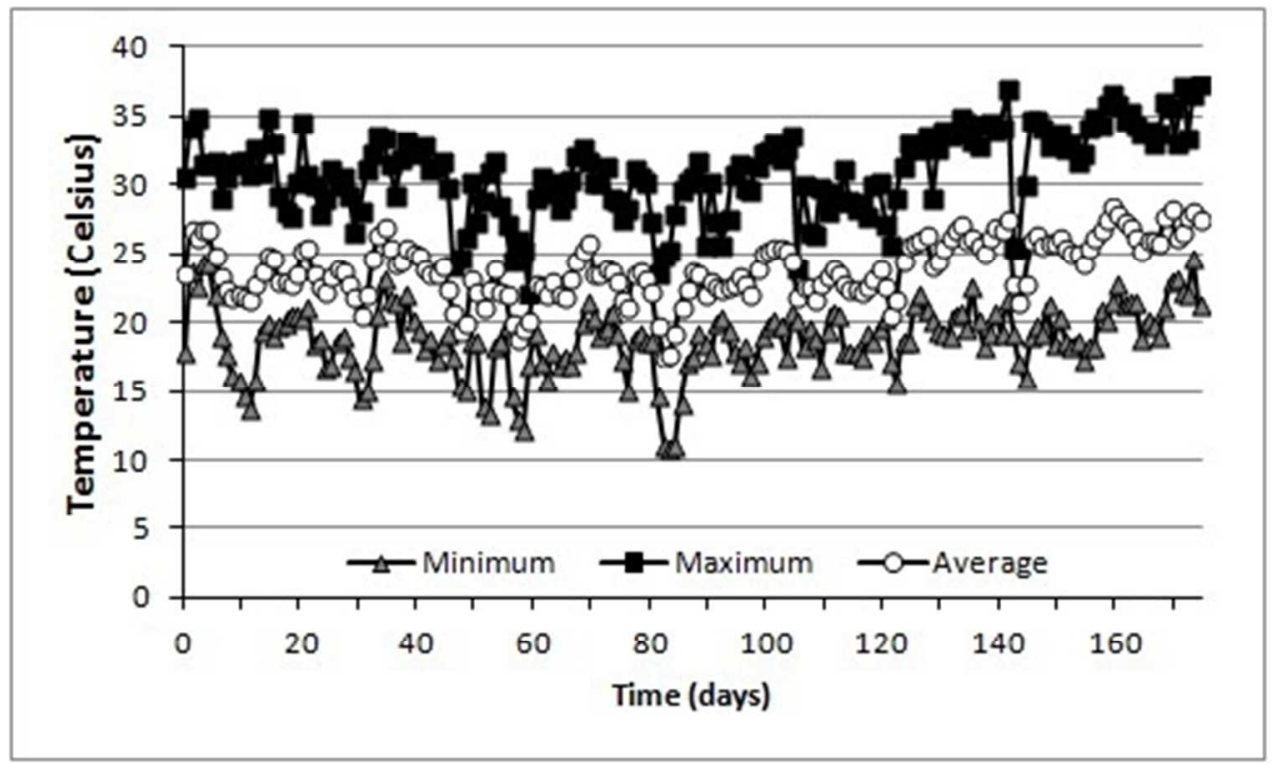

Figure 1. Average, minimum, and maximum temperatures of each day $128 \times 77 \mathrm{~mm}(96 \times 96 \mathrm{DPI})$ 


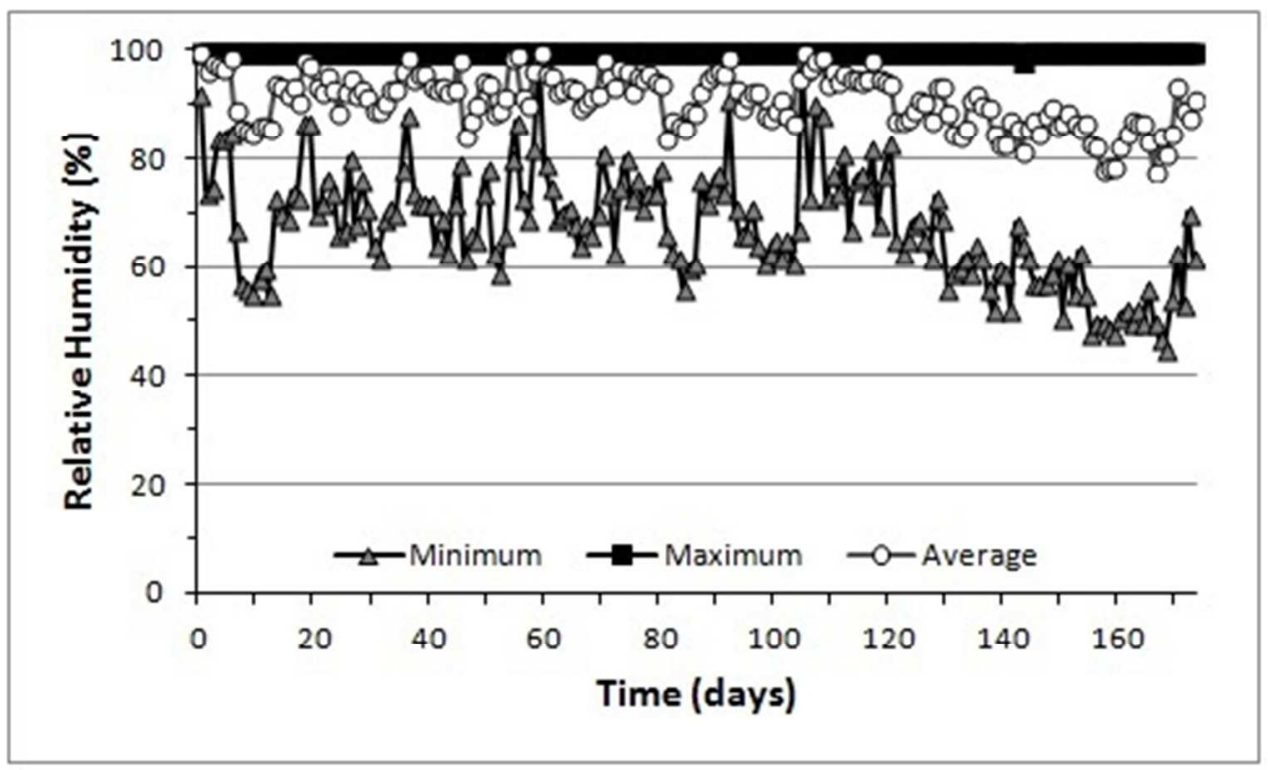

Figure 2. Average, minimum, and maximum relative humidity of each day $128 \times 77 \mathrm{~mm}(96 \times 96 \mathrm{DPI})$ 


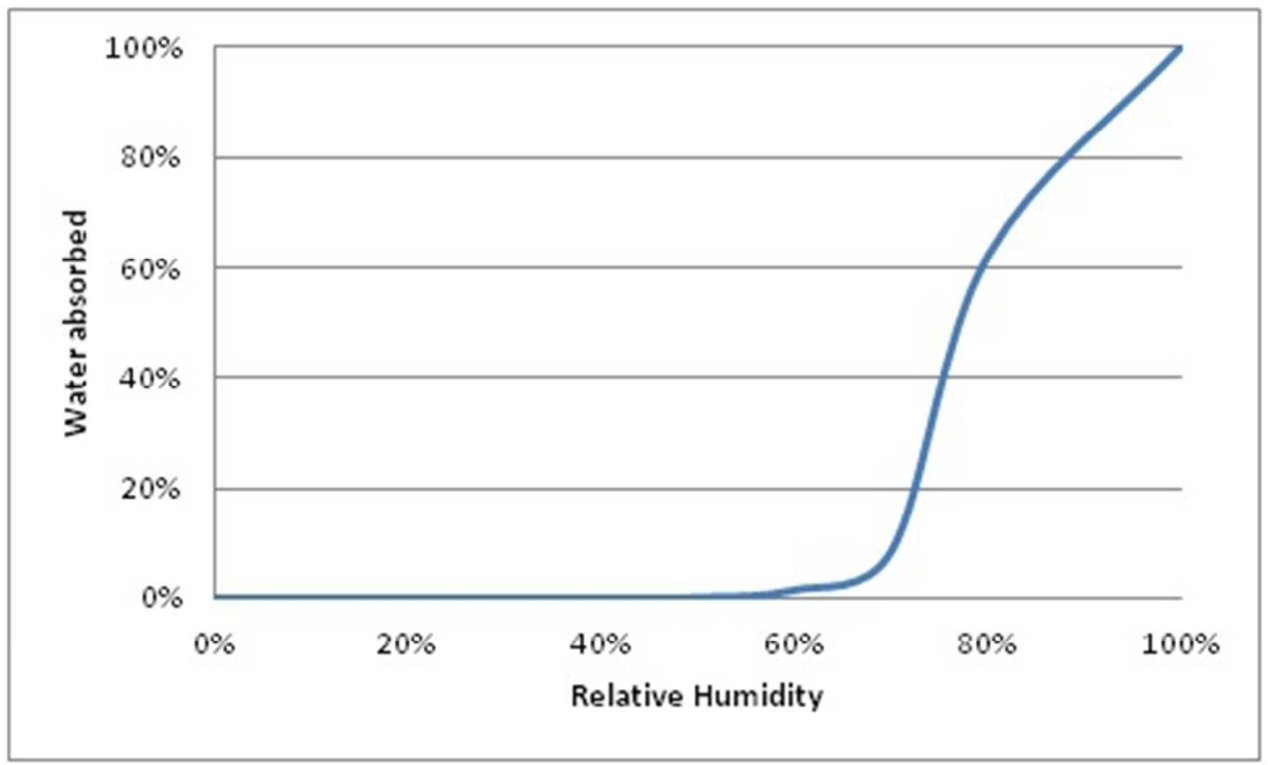

$128 \times 77 \mathrm{~mm}(96 \times 96 \mathrm{DPI})$ 


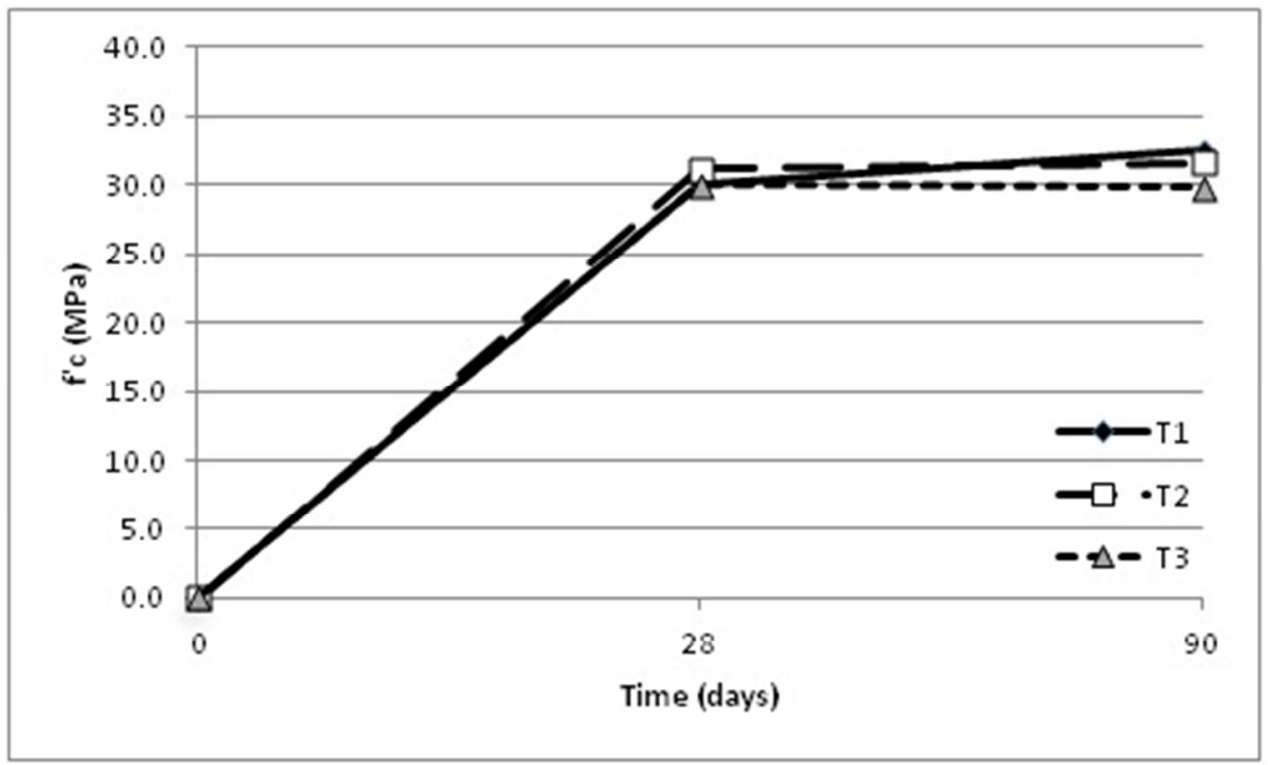

$128 \times 77 \mathrm{~mm}(96 \times 96 \mathrm{DPI})$ 


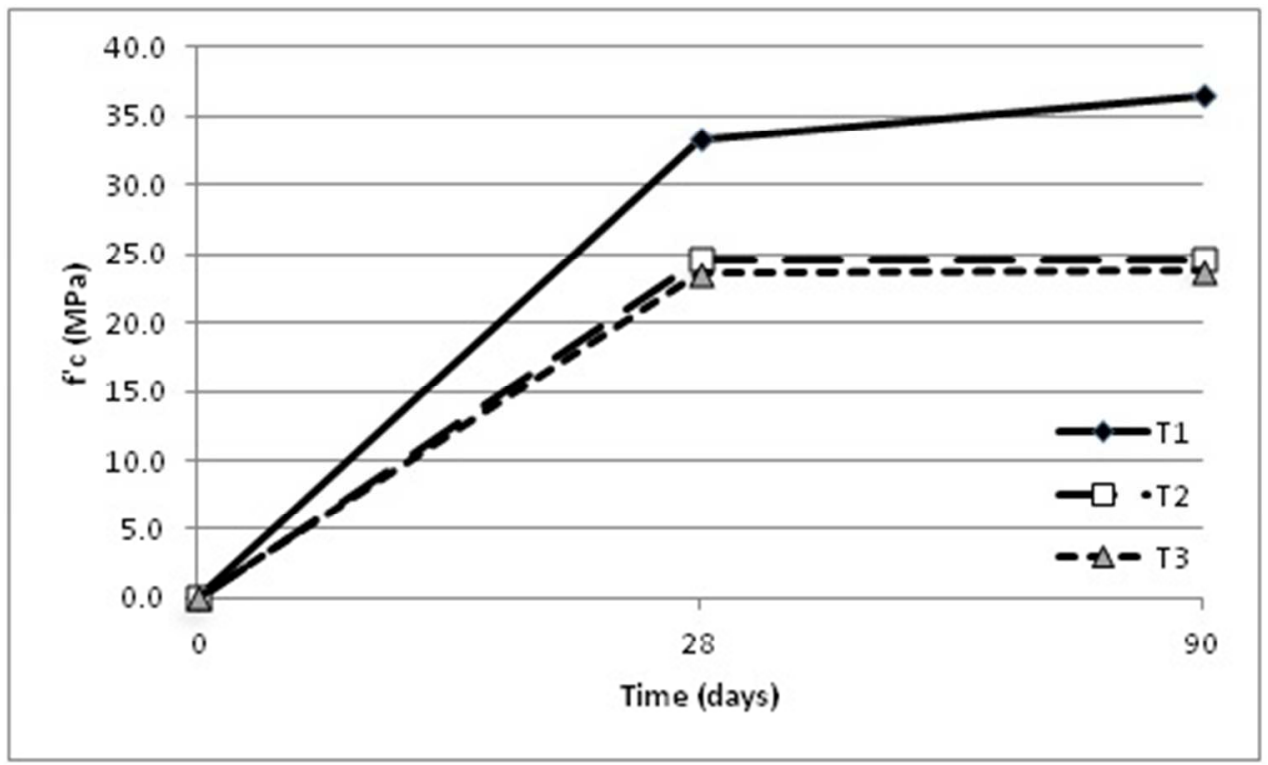

$128 \times 77 m m(96 \times 96$ DPI $)$ 


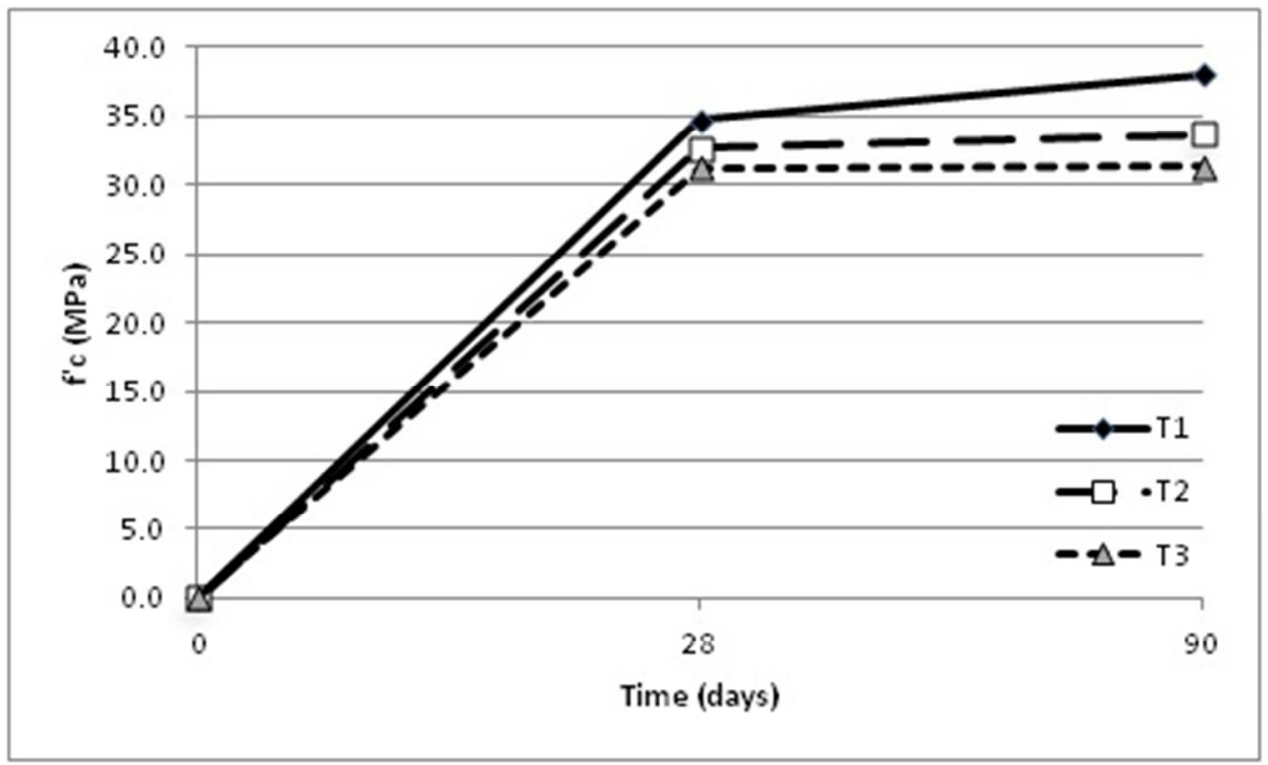

$128 \times 77 \mathrm{~mm}(96 \times 96 \mathrm{DPI})$ 